\title{
INTRODUCTION: LAW AND LANGUAGE; IMPLICATIONS FOR HARMONISATION AND CROSS-BORDER LITIGATION
}

\section{Xandra Kramer ${ }^{*}$}

Law and language are intertwined in many respects. Clearly, the law is expressed in linguistic terms, and by turn linguistic terms bear significance for the interpretation of the law. The study of law and language has a long tradition and is primarily conducted by scholars in the areas of legal theory and linguistics. The focus of the current volume is the implications of law and language for the harmonisation of the law, particularly in the EU context, and for cross-border litigation. Language differences have a significant impact on the process of the harmonisation of the law and on the efficacy of crossborder litigation. ${ }^{1}$

Within the European Union, there are currently 23 official languages. Multilingualism and language equality are to a large degree treasured in the EU. ${ }^{2}$ Language differences are not only a matter of fact, but are also deeply rooted in culture and history, and considered as part of a (national) identity. The desire to protect language rights is reflected in various provisions of EU law, including those of the Treaty on the Functioning of the European Union and, to a certain extent, the EU Charter on Fundamental Rights. ${ }^{3}$ Language rights, for example, encompass the right to speak one of the official languages in the EU institutions and bodies, to address these in one of the official languages and to receive an answer in the same language. Further, legal texts are translated in all the official language of the EU. The protection of language rights, and particular those of minorities, is also perceived as part of the human rights discourse not only in the EU, but also on the domestic and international level. ${ }^{4}$ Important international frameworks focusing are language rights include the European Charter for Regional or Minority Languages, which was established by a body of the Council of Europe in 1992, and the Universal Declaration of Linguistic Rights, proclaimed by UNESCO in 1996.

In multilingual states, including South Africa, Belgium, Switzerland and Canada, language rights are usually guaranteed by the Constitution. These not only include the right to express oneself in one's own language and to be educated in one's own language, but also have important consequences for the legal domain. In different ways and degrees, multilingual states protect language rights in criminal trials and civil litigation and by multilingual publication of legal texts and court judgments.

The lack of a common language and the necessity of legal translation and the inherent interpretation complicate the harmonisation of the law, particularly in the EU where integration is accompanied by a rapid growth of substantive and procedural (private) law. Language differences are also one of the most puzzling obstacles in transnational litigation, where parties often do not speak the same language and where usually one of

\footnotetext{
Professor at Erasmus School of Law, Erasmus University Rotterdam. This contribution and the editorship of this issue has been made possible with the support of the Netherlands Organisation for Scientific Research (NWO) within its Innovational Research Incentives Scheme (VIDI).

See, inter alia, G. Ajani, “"Coherence of European Private Law” and Multilingualism: Two Opposing Principles?', 4 International Business Law Journal 493 (2007); S. Glanert, 'Zur Sprache Gebracht: Rechtsvereinheitlichung in Europa', 2 European Review of Private Law 157 (2006); A. Ryng, 'How to Deal with Language Problems in Cross-Border Litigation in Civil Matters', in P. van der Grinten, P. Meijknecht and F. van der Velden (eds.), Practical Obstacles in Cross Border Litigation (2005) 5; A. Stadler, 'Sprachprobleme im Europäischen Zivilprocessrecht', in P. van der Grinten, P. Meijknecht and F. van der Velden (eds.), Practical Obstacles in Cross Border Litigation (2005) 10.

2 See, inter alia, I. Urrutia and I. Lasagabaster, 'Language Rights as a General Principle of Community Law', 8 German Law Journal 479 (2007). The idea of language rights under EU law is contested by T. Schilling, 'Language Rights in the European Union', 9 German Law Journal 1219 (2008).

3 See, particularly, Arts. 24 and 55 TFEU; Art. 41 Charter of Fundamental Rights of the European Union. 4 See, inter alia, the thematic issue on 'The Human Rights of Linguistic Minorities and Language Policies’, 3(2) International Journal on Multicultural Societies (2001).
} 
the parties has to litigate in a foreign language. As a matter of principle, most countries worldwide exclusively allow court litigation in the official national language(s). ${ }^{5}$ This does not only increase the costs, duration and complexity of cross-border litigation due to the required translations, but also challenge the right to a fair and speedy trial where proper translations are lacking or where language obstacles are frustrating proceedings.

This volume explores the framework of language and the law against the background of the harmonisation of private law in the EU, the obstacles in cross-border litigation and communication between courts and ways to tackle these, the modest introduction of English as an optional court language and the protection of language rights in multilingual states.

The volume includes five contributions. The paper by Simone Glanert, 'Europe, Aporetically: a Common Law Without a Common Discourse' kicks off with a discussion of the Habermasian concept of 'discourse' in the context of the establishment of a European private law. By proponents of a European private law, it is posed that, in absence of a common language, the uniformisation can be ensured through the emergence of a common discourse. In her contribution, Glanert questions the usefulness of this concept. Starting with the biblical myth about the Tower of Babel as a punishment, Astrid Stadler addresses 'Practical Obstacles in Cross-Border Litigation and Communication between (EU) Courts' as a result of the language variety. She poses that although primary EU law provides a high level of protection against discrimination on grounds of language, this is in contrast to the situation of EU citizens involved in cross-border litigation. In their paper 'Tackling Language Obstacles in Cross-Border Litigation: the European Order for Payment and the European Small Claims Procedure Approach', Elena Alina Ontanu and Ekaterina Pannebakker critically review what solutions these two relatively new European harmonised procedures offer. They further address the question in how far these instruments offer a good balance between the aim to simplify cross-border litigation and the right to a fair trial and access to justice. Christoph Kern's paper 'English as a Court Language in Continental Courts' discusses and assesses recent initiatives and reforms to allow English as court language in several European countries. These have raised fundamental debates. Often allowing English as court language in cross-border cases is justified by the desire to attract more litigation. Kern proposes not to restrict the arguments to economic aspects, but to give due weight to the fact that admitting English may facilitate access to justice. The last contribution, by Isabelle Bambust, Albert Kruger and Thalia Kruger, on 'Constitutional and Judicial Language Protection in Multilingual States: A Brief Overview of South Africa and Belgium' compares the legal impact of multilingualism in these two selected countries. In South Africa, the eleven official languages do not receive the same protection for considerations of practicality. In Belgium, strict language rules exist, based on strong principles of territoriality and monolingualism. It reveals the gap between the ideal of language rights and practice.

These five contributions provide a valuable insight in the complex issue of harmonisation and cross-border litigation, as well as language rights issues on the domestic level. These will only become more important as the harmonisation of law and the number of cross-border transactions and litigations increase with the pace of European integration and economic globalisation.

See, in this respect, also Art. 6 of the ALI/UNIDROIT Principles on Transnational Civil Litigation, as adopted in 2004 . 